\section{NEW ANTIBIOTICS, CLAZAMYCINS A AND B}

Sir:

Two chlorine-containing antibiotics, clazamycins A and B have been isolated from the culture broth of Streptomyces No. MF990-BF4 which is closely related to Streptomyces violaceorectus $^{1)}$ and Streptomyces cinereoruber ${ }^{2)}$.

The strain was cultured at $27^{\circ} \mathrm{C}$ for 67 hours on a rotatory shaker (180 r.p.m.) in a medium containing $1.5 \%$ glycerol, $1.5 \%$ cotton seed meal, $0.3 \% \mathrm{NaCl}$ and $0.2 \% \mathrm{~L}$-asparagine (adjusted to $\mathrm{pH}$ 7.4). Vegetative inoculum, $3 \%$ by volume, grown for 24 hours in the same medium was used. The culture broth in 45 flasks was collected and filtered (4.6 liters, $76 \mu \mathrm{g} / \mathrm{ml}$ of clazamycins) using Hyflo Supercel as the filter aid. Concentrations of clazamycins were determined by the usual cylinder plate method against Pseudomonas aeruginosa No. 12, using crystalline clazamycin A hydrochloride ( $826 \mu \mathrm{g} / \mathrm{mg}$ ) as the assay standard.

The antibiotics in the filtrate were adsorbed on a column of Amberlite IRC-50 $\left(70 \% \mathrm{Na}^{+}\right.$form, $400 \mathrm{ml}$ ) and eluted with $0.5 \mathrm{~N}$ hydrochloric acid. The active neutral eluate $(945 \mathrm{ml})$ was concentrated to dryness $(14.9 \mathrm{~g})$ and the residue was extracted with $60 \mathrm{ml}$ of methanol. The extract was concentrated and dissolved in $70 \mathrm{ml}$ of water. The antibiotics in the aqueous solution were purified by column chromatographies on Amberlite XAD-2 $(180 \mathrm{ml})$ and on activated carbon $(17 \mathrm{ml})$ eluting with water. The active eluate was concentrated to dryness yielding a mixture $(314 \mathrm{mg}$, $558 \mu \mathrm{g} / \mathrm{mg}$ ) of clazamycins A and B (hydrochlorides).

The mixture was dissolved in $1.5 \mathrm{ml}$ of water and adsorbed on a column of Amberlite XAD-2 $(300 \mathrm{ml})$. The column was eluted with water and the eluate was cut into each $10-\mathrm{ml}$ fractions. Fractions $22 \sim 26$ were combined and concentrated to dryness yielding a colorless powder $(124 \mathrm{mg}$, $593 \mu \mathrm{g} / \mathrm{mg}$ ) of clazamycin B hydrochloride. The hydrochloride was further purified by rechromatography on Amberlite XAD-2, yielding pure clazamycin B hydrochloride $(660 \mu \mathrm{g} / \mathrm{mg})$. Fractions $27 \sim 45$ were combined and concentrated to yield pure clazamycin A hydrochloride $(83 \mathrm{mg}$, $826 \mu \mathrm{g} / \mathrm{mg}$ ) which crystallized in a mixture of ethanol and ethyl acetate.

Clazamycin A hydrochloride is obtained as colorless crystals melting at $110^{\circ} \mathrm{C}$ with decomposition. $[\alpha]_{D}^{25}-56^{\circ}$ (c 1.0, water). Anal calcd. for $\mathrm{C}_{7} \mathrm{H}_{9} \mathrm{~N}_{2} \mathrm{OCl} \cdot \mathrm{HCl}: \quad \mathrm{C} 40.21, \mathrm{H} 4.82, \mathrm{~N} 13.39$, $\mathrm{Cl}$ 33.91. Found: C 40.12, H 4.80, N 13.26, $\mathrm{Cl}$ 34.06. The molecular formula is also derived by the high-resolution MS spectrum (calcd. mol. wt. for $\mathrm{C}_{7} \mathrm{H}_{9} \mathrm{~N}_{2} \mathrm{OCl}, 172.0402$; found $\mathrm{m} / \mathrm{e}$ 172.0401). The hydrochloride shows UV maxima at $212 \mathrm{~nm}(\epsilon 11,800)$ and $250 \mathrm{~nm}(\epsilon 2,600)$ in an aqueous solution.

Clazamycin B hydrochloride obtained as a colorless hygroscopic powder shows no definite melting point. $[\alpha]_{D}^{24}+96^{\circ}$ ( $c 1.0$, water). The same molecular formula is derived by the high-resolution MS spectrum (calcd. mol. wt. for $\mathrm{C}_{7} \mathrm{H}_{9} \mathrm{~N}_{2}$ $\mathrm{OCl}, 172.0402$; found $\mathrm{m} / \mathrm{e}$ 172.0422). The hydrochloride shows UV maxima at $212 \mathrm{~nm}(\epsilon 9,500)$ and $250 \mathrm{~nm}(\epsilon 1,830)$ in an aqueous solution.

The IR spectra of clazamycins A and B are represented in Figs. 1 and 2, respectively. The PMR and CMR chemical shifts of clazamycins $\mathrm{A}$ and $\mathrm{B}$ are shown in Tables 1 and 2. Both clazamycins A and B give positive RYDON-SMITH and pentacyanoaquoferriate reactions and negative ninhydrin reaction. Their hydrochlorides are soluble in water and lower alcohols. By high-voltage paper electrophoresis with $3,500 \mathrm{~V}$ for 15 minutes in formic acid - acetic acid - water $(1: 3: 36, v / v)$, both antibiotics move to the cathode with $\mathrm{Rm}$ (relative mobility to alanine) 1.10 . Clazamycins A (Rf 0.40) and B (Rf 0.27) can be separated by thin-layer chromatography using Silica gel G (Merck, Art. 5715) with butanol acetic acid - water $(6: 1: 2, \mathrm{v} / \mathrm{v})$.

Clazamycin A is stable in an aqueous solution at $\mathrm{pH} 2.2$ for 24 hours at room temperature, but

Table 1. PMR chemical shifts of clazamycins A and B (hydrochlorides)

\begin{tabular}{l|l|l}
\hline \multirow{2}{*}{ Proton } & \multicolumn{2}{|c}{$\delta \mathrm{ppm}(\mathrm{J} \mathrm{Hz})$} \\
\cline { 2 - 3 } & Clazamycin A & \multicolumn{1}{|c}{ Clazamycin B } \\
\hline $1-\mathrm{H}$ & $7.95 \mathrm{~d}(6.0)$ & $7.94 \mathrm{~d}(5.9)$ \\
$2-\mathrm{H}$ & $7.07 \mathrm{~d}(6.0)$ & $7.03 \mathrm{~d}(5.9)$ \\
$4-\mathrm{H}_{2}$ & $4.29 \mathrm{q}(5.0,13)$ & $4.42 \mathrm{q}(3.1,13)$ \\
& $4.69 \mathrm{q}(6.3,13)$ & $4.79 \mathrm{q}(7.2,13)$ \\
$5-\mathrm{H}$ & $5.59 \mathrm{~m}$ & $5.62 \mathrm{~m}$ \\
$6-\mathrm{H}_{2}$ & $2.82 \mathrm{q}(7.5,14)$ & $3.05 \mathrm{~d}(4.5)$ \\
& $3.28 \mathrm{q}(6.3,14)$ & \\
\hline
\end{tabular}

Chemical shifts, $\delta(\mathrm{ppm})$ were measured in $\mathrm{D}_{2} \mathrm{O}$ using TMS as the external reference. 
clazamycin $\mathrm{B}$ is converted to a mixture of $\mathrm{A}$ and B (1:3). An equilibrium conversion of clazamycins was analyzed by thin-layer chromatographic technique. Clazamycin A or B was converted to a mixture of $\mathrm{A}$ and $\mathrm{B}(3: 2)$ in an aqueous solution at $>\mathrm{pH} 6.8$ for 24 hours at room temperature.

The structure of clazamycin A was determined to be $(5 S, 6 \mathrm{a} R)$-5-chloro-4,5,6,6a-tetrahydro-6ahydroxy-3-imino- $3 \mathrm{H}$-3a-azapentalene by $\mathrm{X}$-ray crystallographic analysis of its hydrochloride as described in a following paper ${ }^{3)}$. PMR and CMR signals of clazamycin A can reasonably be assigned as shown in Tables 1 and 2, respectively. The structure of clazamycin B is confirmed to be a 6a-epimer of clazamycin A by spectral data of its hydrochloride (Tables 1 and 2) and by equilibrium conversion of clazamycins.

Clazamycins A and B have weak antibacterial activities, as shown in Table 3. In the treatment with daily intravenous doses of $12.5 \sim 100 \mu \mathrm{g}$ of clazamycin A per mouse for 10 days, more than $130 \%$ prolongations in the survival period of mice inoculated with leukemia L-1210 cells were ob-

Table 2. Carbon-13 chemical shifts of clazamycins A and $\mathrm{B}$ (hydrochlorides) in $\mathrm{D}_{2} \mathrm{O}$.

\begin{tabular}{c|c|c}
\hline \multirow{2}{*}{ Carbon } & \multicolumn{2}{|c}{ Chemical shifts $(\delta)$} \\
\cline { 2 - 3 } & Clazamycin A & Clazamycin B \\
\hline 1 & $154.0 \mathrm{~d}$ & $153.4 \mathrm{~d}$ \\
2 & $123.3 \mathrm{~d}$ & $123.2 \mathrm{~d}$ \\
3 & $169.0 \mathrm{~s}$ & $167.9 \mathrm{~s}$ \\
4 & $53.8 \mathrm{t}$ & $55.0 \mathrm{t}$ \\
5 & $60.1 \mathrm{~d}$ & $60.4 \mathrm{~d}$ \\
6 & $43.2 \mathrm{t}$ & $42.3 \mathrm{t}$ \\
$6 \mathrm{a}$ & $104.2 \mathrm{~s}$ & $105.0 \mathrm{~s}$ \\
\hline
\end{tabular}

$\delta:$ ppm from TMS using dioxane $(\delta=67.4 \mathrm{ppm})$ as the internal reference.

s,d,t: Multiplicity of off-resonance.

Fig. 1. The IR spectrum of clazamycin A hydrochloride in KBr.

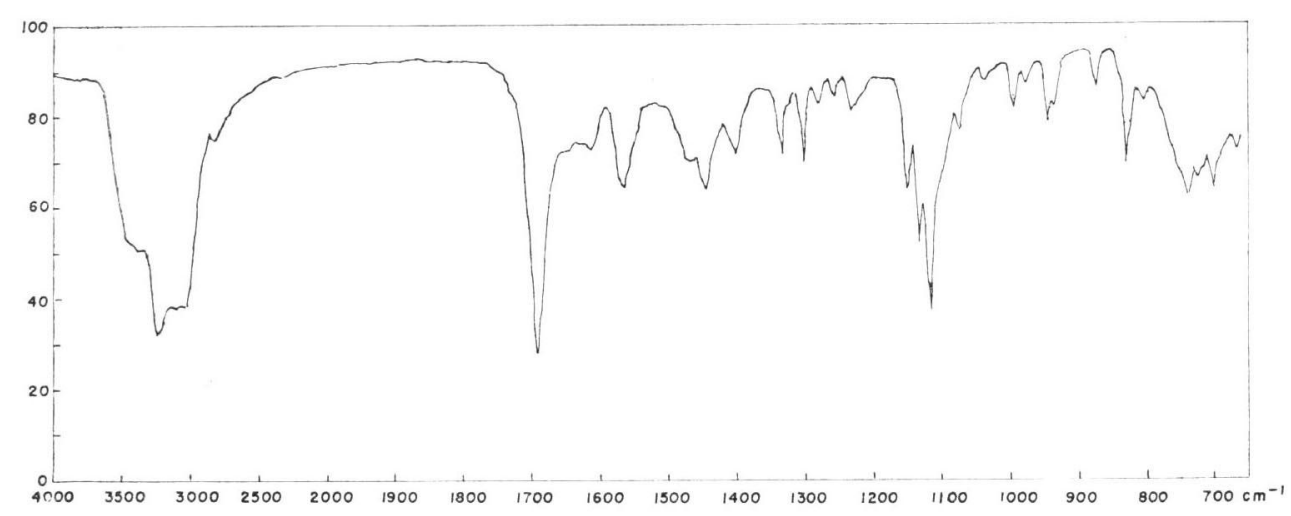

Fig. 2. The IR spectrum of clazamycin B hydrochloride in $\mathrm{KBr}$.

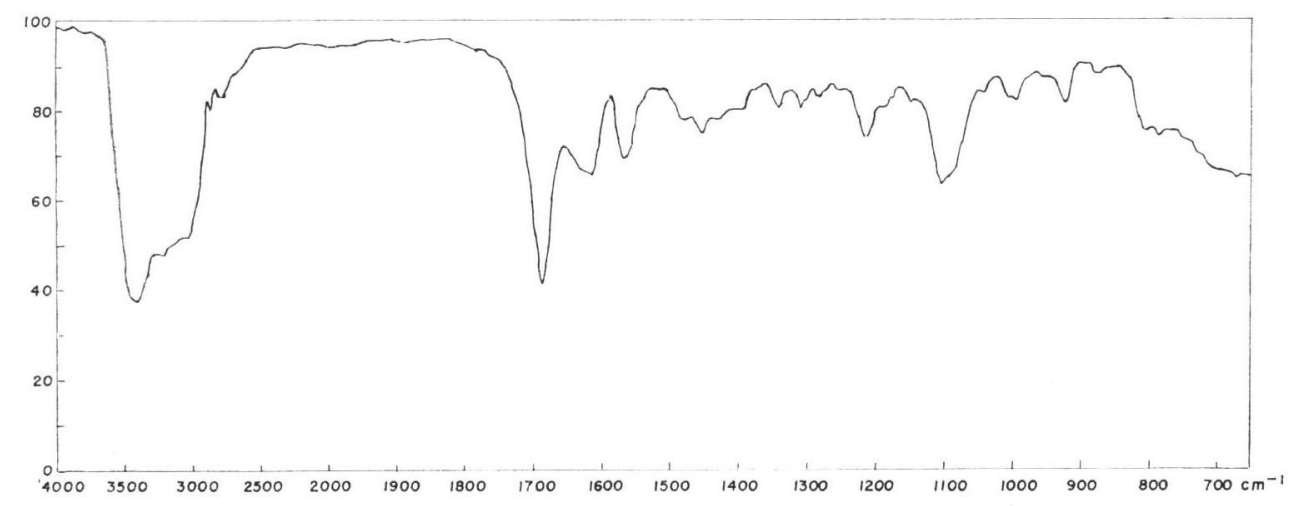


Table 3. The antimicrobial spectra of clazamycins (hydrochloride).

\begin{tabular}{|c|c|c|c|c|c|}
\hline \multirow[t]{2}{*}{ Test organisms } & \multicolumn{2}{|c|}{$\begin{array}{c}\text { Minimum inhibitory } \\
\text { concentrations } \\
(\mu \mathrm{g} / \mathrm{ml})\end{array}$} & \multirow[t]{2}{*}{ Test organisms } & \multicolumn{2}{|c|}{$\begin{array}{c}\text { Minimum inhibitory } \\
\text { concentrations } \\
(\mu \mathrm{g} / \mathrm{ml})\end{array}$} \\
\hline & $\begin{array}{c}\text { Clazamycin } \\
\text { A }\end{array}$ & $\begin{array}{c}\text { Clazamycin } \\
\text { B }\end{array}$ & & $\begin{array}{c}\text { Clazamycin } \\
\text { A }\end{array}$ & $\begin{array}{c}\text { Clazamycin } \\
\text { B }\end{array}$ \\
\hline $\begin{array}{l}\text { Staphylococcus aureus } \\
\text { FDA209P }\end{array}$ & 100 & 100 & $\begin{array}{l}\text { Klebsiella pneumoniae } \\
\text { PCI602 }\end{array}$ & 25 & 50 \\
\hline $\begin{array}{l}\text { Staphylococcus aureus } \\
\text { Smith }\end{array}$ & 100 & 100 & $\begin{array}{l}\text { Klebsiella pneumoniae } \\
22 \$ 3038\end{array}$ & 50 & 100 \\
\hline $\begin{array}{l}\text { Micrococcus flavus } \\
\text { FDA16 }\end{array}$ & 25 & 25 & $\begin{array}{l}\text { Shigella dysenteriae } \\
\quad \text { JS11910 }\end{array}$ & 25 & 25 \\
\hline Sarcina lutea PCI1001 & 100 & 100 & $\begin{array}{l}\text { Shigella flexneri } \\
\text { 4b JS } 11811\end{array}$ & 12.5 & 25 \\
\hline Bacillus anthracis & 6.25 & 12.5 & Shigella sonnei JS11746 & 25 & 25 \\
\hline Bacillus subtilis PCI219 & 100 & 100 & Salmonella typhi T-63 & 25 & 12.5 \\
\hline $\begin{array}{l}\text { Bacillus subtilis } \\
\text { NRRL B-558 }\end{array}$ & 100 & 100 & $\begin{array}{l}\text { Salmonella enteritidis } \\
\quad 1891\end{array}$ & 25 & 50 \\
\hline $\begin{array}{l}\text { Corynebacterium bovis } \\
1810\end{array}$ & 100 & 100 & Proteus vulgaris OX19 & 25 & 25 \\
\hline Escherichia coli NIHJ & 100 & 100 & $\begin{array}{l}\text { Pseudomonas aeruginosa } \\
\text { A3 }\end{array}$ & 25 & 12.5 \\
\hline Escherichia coli $\mathrm{K}-12$ & 50 & 50 & $\begin{array}{l}\text { Pseudomonas aeruginosa } \\
\text { No. } 12\end{array}$ & 100 & 100 \\
\hline Escherichia coli ML 1629 & 50 & 50 & Pseudomonas aeruginosa & 50 & 50 \\
\hline Escherichia coli ML 1410 & 50 & 50 & $\begin{array}{l}\text { 11-13 } \\
\text { Pseudomonas aeruginosa }\end{array}$ & 50 & 25 \\
\hline $\begin{array}{l}\text { Escherichia coli } \\
\text { ML } 1410 \text { R81 }\end{array}$ & 50 & 50 & $\begin{array}{l}\text { GN315 } \\
\text { Pseudomonas aeruginosa }\end{array}$ & 25 & 25 \\
\hline Escherichia coli W677 & 50 & 50 & K-Ps102 & & \\
\hline $\begin{array}{l}\text { Escherichia coli } \\
\text { JR66/W677 }\end{array}$ & 50 & 50 & $\begin{array}{l}\text { Pseudomonas maltophilia } \\
\text { GN907 }\end{array}$ & 50 & 50 \\
\hline
\end{tabular}

Bacteria were incubated on a $0.5 \%$ peptone agar plate at $37^{\circ} \mathrm{C}$ for 17 hours.

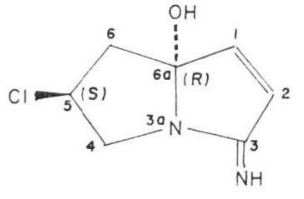

Clazamycin A

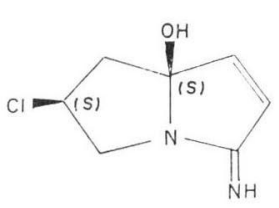

Clazamycin B served. Intravenous acute $\mathrm{LD}_{50}$ of clazamycins $\mathrm{A}$ and $\mathrm{B}$ in mice were $50 \sim 100 \mathrm{mg} / \mathrm{kg}$ and $>100$ $\mathrm{mg} / \mathrm{kg}$, respectively.

Dihydroclazamycin A (m/e 174) prepared by hydrogenation of clazamycin $\mathrm{A}$ with palladium on carbon in water has no antibacterial activity.

\section{Acknowledgement}

This work was partly supported by a grant-in-aid for cancer research from the Ministry of Education, Science and Culture in Japan.

\section{YUKIO HORIUCHI \\ SHINICHI KONDO \\ TAKAKO IKEDA \\ DAISHIRO IKEDA}

Keiko Miura

Masa Hamada

TOMIO TAKEUCHI

Hamao Umezawa

Institute of Microbial Chemistry 14-23, Kamiosaki 3-chome, Shinagawa-ku, Tokyo 141, Japan

(Received May 11, 1979)

\section{References}

1) Shirling, E. B. \& D. Gottlieb: Cooperative description of type cultures of Streptomyces. IV. Species descriptions from second, third and fourth studies. Int. J. System. Bacteriol. 19: $391 \sim 512,1969$

2) Shirling, E. B. \& D. Gottlieb: Cooperative description of type cultures of Streptomyces. II. Species descriptions from first study. Int. J. System. Bacteriol. 18: 69 189, 1968

3) Nakamura, H.; Y. ItTAKe \& H. Umezawa: Crystal and molecular structure of clazamycin A. J. Antibiotics 32: 765 767, 1979 